\title{
濃度補償フイルタの被曝線量低減効果
}

\author{
勝田稔三・中島、直 - 桑野忠雄 \\ 上田 講 記*・佐々木 靖 広・吉田次郎 \\ 大阪府立成人病センター放射線診断科放射線技師室 \\ *(現)大阪がん予防検診センター検診第一部
}

（論文受理１992年 7 月15日）

（最終論文受理１992年11月20日）

(Code No. 114.2, 496.9)

Key words : exposure dose, area dose, compensating filter.

\section{EFFECT OF EXPOSURE DOSE REDUCTION USING A COMPENSATING FILTER}

\author{
Toshizo Katsuda, Tadashi Nakajima, Tadao Kuwano \\ Kouki Ueda*, Yasuhiro Sasaki, Jiro Yoshida
}

Radiological Technology Section, Department of Diagnostic Radiology. The Center for Adult Diseases, Osaka.

* Presently: The Osaka Cancer Prevention and Detection Center.

\section{Summary}

It is empirically said that the application of the compensating filter leads to a decrease in the exposure dose of the filter-inserted area and an increase in that of the otherwise area. Using the area-dosimeter, comparison was made of exposure doses by the application of the above filter and the otherwise filter in head simple X-P, abdominal angiography and lower extremity X-P. Using the filter for head simple X-P and Mix-Dp phantom, measurement was made of the absorbed dose at the $5 \mathrm{~cm}$-depth to compare the rate of decrease in absorbed dose between the above both areas.

Head simple X-P gained a decrease in area dose of $29 \%$. The absorbed dose at the $5 \mathrm{~cm}$-depth in the phantom experiment showed a decrease of over $26 \%$ at the filter-inserted area, but little increase at the otherwise area.

The above results indicated the interposition of the filter between the X-ray tube and the object to lead to decreases not only in the area dose but also in the patient's exposure dose. 


\section{1.はじめに}

一枚のX線写真を考えた場合, 写真濃度は低濃度部か ら高濃度部まで分布している。被写体厚の厚い部分を適 正濃度領域としX線を照射すると, 薄い部分は過濃度と なる，過濃度部分は読影不能となり，被検者にとっては 単にX線を被曝したのみと考えられる。濃度補償フイル タ（以下フイルタ）はこの過濃度を緩和し, 読影可能に 寸る目的で使用される ${ }^{1 \sim 5)}$. しかし，被検者の被懪線量低 減に関して考察されたことはほとんどない.フイルタを X線管と被写体間仁位置させ X線を照射すると, フイル 夕領域の照射線量が減少する。これは被検者の被曝線量 も低滅されている可能性を意味する。また，フイル夕を 挿入するとX線管負荷が増加するともいわれている6 $\mathrm{X}$ 線管負荷が増加すると, フィルタ未挿入領域の被嚗線 量の増加が伴うとも経験的にいわれているが，定量的に 評価した例はない，著者らはフイルタの使用頻度を高め ることにより，被検者の被懪低減が可能と考元た。フイ ル夕使用, 非使用での面積線量の低減率を求め, 被検者 の被懪線量低減を定量的に評価した。また, 頭部用フイ ルタとファントムを用いフイルタ挿入部抢よび未挿入部 に扔けるフイルタ使用, 非使用での吸収線量も比較した ので報告する。

\section{2. 方法および材料}

\section{1 使用フイルタ}

使用したフイルタは当成人病センターにおいて作製し た物を用いた。

頭部単純撮影用フイルタはアルミニウムを用い, 当成 人病センターの撮影条件に添うよう最大厚を $20 \mathrm{~mm}$ と し作製した（Fig.1）。

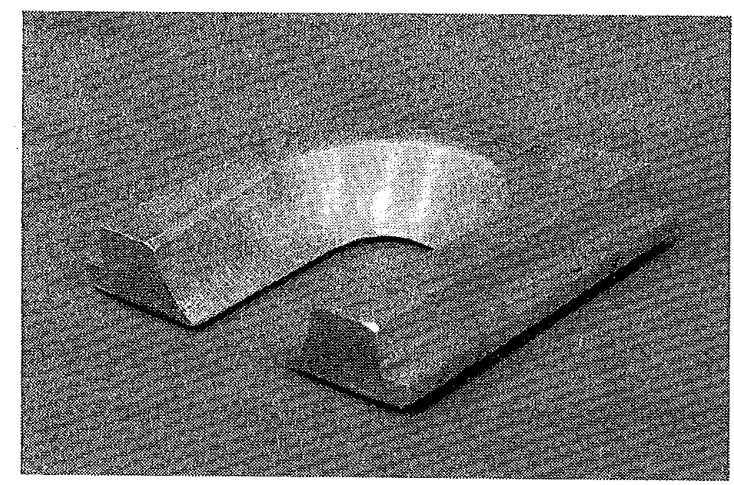

Fig. 1 An alminum compensating filter for skull radiography. Maximum thickness $20 \mathrm{~mm}$
腹部血管造影用フイル夕は横隔膜部用と側腹壁部用の 2 種類を用いた。横隔膜部用フイルタは当成人病センタ 一において開発作製した物で，アルミニウムを用い最大 厭 $20 \mathrm{~mm}$ とした ${ }^{1,6)}$ (Fig. 2A)。また，側腹壁部用フイル 夕は新開》らが開発したフイル夕を基準としたが，材料 に $1 \mathrm{~mm}$ 当たり $0.02 \mathrm{mmPb}$ 当量の含鉛アクリル $14 \mathrm{~mm}$ 厚を用いた (Fig. 2B).

下肢長尺撮影用フイルタは感度補償増感紙 US-II（化 成オプトニクス社製）に一致するように当成人病センタ 一に扔いて開発作製した。 $1 \mathrm{~mm}$ 当たり $0.043 \mathrm{mmPb}$ 当 量の含鉛アクリルを用い最大厚 $3.5 \mathrm{~mm}$ とした ${ }^{8)}$ (Fig. 3).

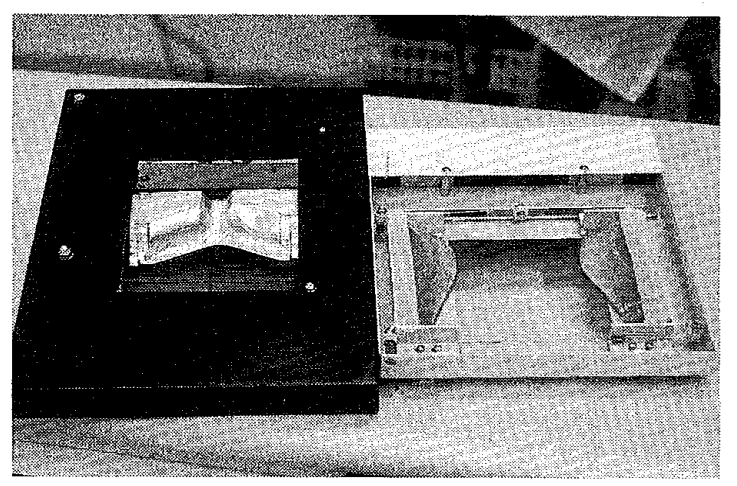

A

B

Fig. 2 A : An aluminum compensating filter over a diaphragmatic region for hepatic angiography. Maximum thickness 20 $\mathrm{mm}$. B : Lateral filters for hepatic angiography. These were made of leadloded acrylic material $(0.02 \mathrm{~mm} \mathrm{~Pb}$ equivalent par $1 \mathrm{~mm}$ ). Maximum thickness of these are $14 \mathrm{~mm}$.

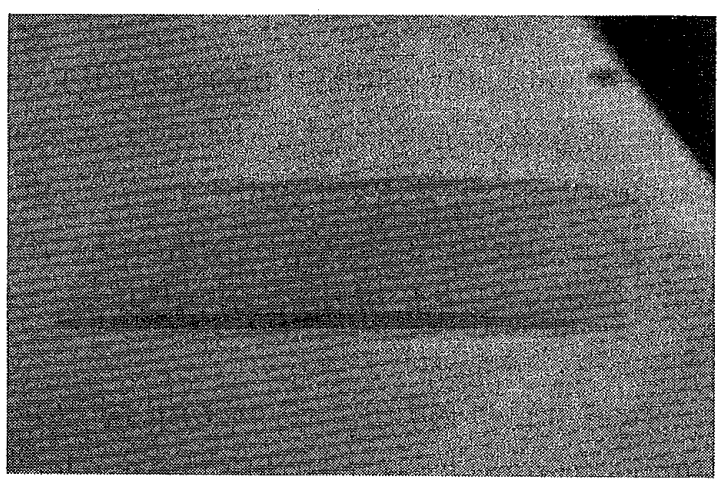

Fig.3 A compensating filter for full length of lower extremity radiography. This was made of lead-loded acrylic material $(0$. $043 \mathrm{~mm} \mathrm{~Pb}$ equivalent par $1 \mathrm{~mm}$ ). Maximum thickness of it is $3.5 \mathrm{~mm}$. 


\section{2 面積線量低減率の測定}

画像生成に関与しかつ不必要なX線のフイル夕による 低減率を調べるため, 次の 3 種の撮影法において, PTW - FREIBURG 社製面積線量計 DIAMENTOR - M (VICTOREEN 社製 RADOCON II 型33 cc 指頭型プロ ーブにて校正）および人体ファントムを用いフイル夕使 用非使用での面積線量を測定した。1）頭部単純正面撮 影：照射野の大きさ $25.4 \mathrm{~cm} \times 30.5 \mathrm{~cm}$ ，焦点フイルム間 距離 (SFD) $110 \mathrm{~cm}$, 管電圧 $75 \mathrm{kV}$, Photo timer 撮影 (Siemens 社製 Orbix と Polydoros 50S を使用)．2）腹 部血管造影：照射野 $35 \mathrm{~cm} \times 35 \mathrm{~cm}, \mathrm{SFD} 100 \mathrm{~cm}$, 管電圧 $75 \mathrm{kV}$, Photo timer 撮影 (Philips 社製 super -100 使 用).3）下肢長尺撮影：照射野 $35.0 \mathrm{~cm} \times 105 \mathrm{~cm}$, SFD $260 \mathrm{~cm}$, 管電圧 $80 \mathrm{kV}, 200 \mathrm{~mA}, 0.8 \mathrm{sec}$ (東芝社製 $\mathrm{KX} 015$ を使用).Fig. 4 亿面積線量計と頭部単純撮影用フイルタ の設定位置の模式図を示す.

\section{3 ファントムによる $5 \mathrm{~cm}$ 深部での吸収線量の測} 定

被嚗線量が低減されていることを調べるため，頭部単 純正面撮影用フイルタを用いファントム実験をおこなっ た.

$\mathrm{Mix}-\mathrm{Dp}$ 厚 $20 \mathrm{~cm}$ のファントム内で, 表面から $5 \mathrm{~cm}$ の位置に指頭型3 3 cc プローブ（VICTOREEN 社製 RADOCON II型を使用）を置き，X線束中心および2.5 $\mathrm{cm}$ の間隔で $10 \mathrm{~cm}$ までの 5 点においてフイル夕使用, 非使用時の吸収線量を測定した。照射野は $25.4 \mathrm{~cm} \times$ $30.5 \mathrm{~cm}$, SFD $110 \mathrm{~cm}$, 管電圧 $75 \mathrm{kV}$ とし, 写真中心の 濃度を一定にする条件にて照射した（Siemens 社製 Orbix と Polydoros 50S を使用)。な㧍, 測定方向は冠状 面方向にて測定したので，X線管の方向は長軸方向とな つた.

\section{3. 結果}

\section{1 面積線量低減率の測定}

頭部単純撮影での面積線量は, フイルタ非使用時に 35 $\mathrm{R} \cdot \mathrm{cm}^{2}\left(1 \mathrm{R}=2.58 \times 10^{-4} \mathrm{C} / \mathrm{kg}\right)$, 使用時に $25 \mathrm{R} \cdot \mathrm{cm}^{2}$ と なり, 面積線量低減率は $29 \%$ になった。腹部血管造影お よび下肢長尺撮影の結果を Table 1 に示す。また，それ ぞれの撮影方法におけるX線管負荷の増加を Table 2 に 示寸.

\section{2 ファントムによる $5 \mathrm{~cm}$ 深部での吸収線量の測 定}

フイルタ非使用時の測定值を $100 \%$ として比較すると， フイルタ使用時X線中心軸上で $104 \%$ と増加した. X線中

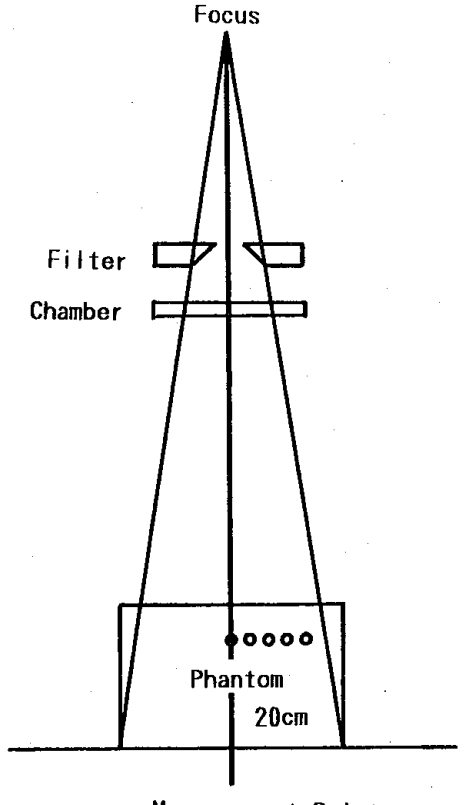

Fig. 4 A schematic diagram of measurement points of area dose and absorbed doses. Area dosimeter is placed between filters and phantom. Absorbed doses were measured at $5 \mathrm{~cm}$ depth in a Mix-Dp phantom. Distances between the adjacent two measurement points are $2.5 \mathrm{~cm}$. Thickness of a phantom is $20 \mathrm{~cm}$. Measurements were performed in the axial direction for to use skull radiography.

Table 1 Comparison of area doses among three different radiograms

\begin{tabular}{lrrc}
\hline \hline \multicolumn{2}{c}{ Area Dose $\left(\mathrm{R} \cdot \mathrm{cm}^{2}\right)^{*}$} & Reduction $(\%)$ \\
\hline \multicolumn{1}{c}{ Filter } & $(-)$ & $(+)$ & \\
\hline Skull & 35 & 25 & 29 \\
\hline Hepatic & 136 & 72 & 47 \\
\hline Lower Extremity & 338 & 77 & 80 \\
\hline
\end{tabular}

${ }^{*} 1 \mathrm{R}=2.58 \times 10^{-4} \mathrm{C} / \mathrm{kg}$

Table 2 Tube loads increasing among three different radiograms

\begin{tabular}{lccc}
\hline & mAs & & increase (\%) \\
\hline \multicolumn{1}{c}{ Filter } & $(-)$ & $(+)$ & \\
\hline Skull & 25 & 28 & 12.0 \\
\hline Hepatic & 21 & 23 & 9.5 \\
\hline Lower Extremity & 16 & 16 & 0.0 \\
\hline
\end{tabular}




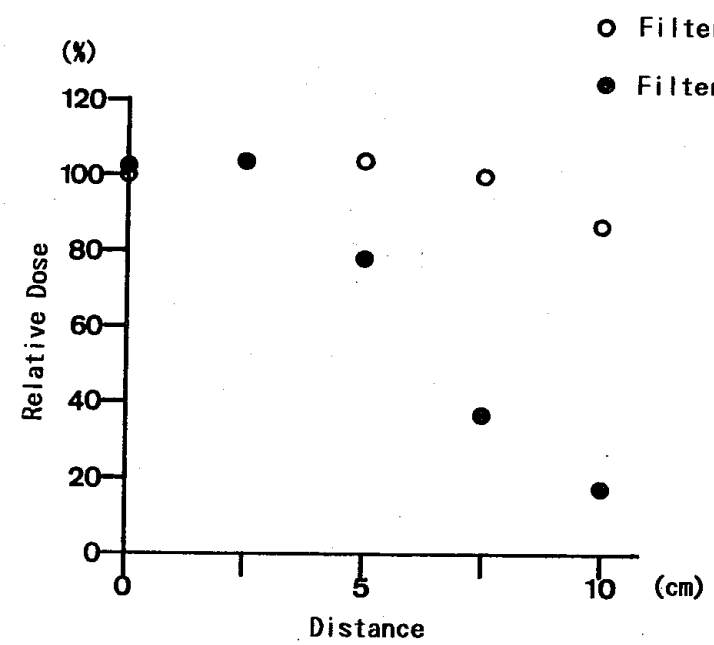

Fig. 5 Results of measurement of absorbed doses at a $5 \mathrm{~cm}$ depth in a phantom were plotted based on a measurement value at the isocenter without any filter.

Marks "O" are the measurement values that were taken without any filter.

Marks "•" are the measurement values that were taken with a filter.

心軸上から $2.5 \mathrm{~cm}$ の位置ではフイルタ使用, 非使用とも 同值となり変化がなかった。しかし， $5 \mathrm{~cm}$ 離れた点では 急激に測定值が減少し，フイルタを使用で $74 \%$ となり線 量低減率は26\%であった。

次に $7.5 \mathrm{~cm}$ 離れた位置ではフイルタ使用で $36 \%$ とな り線量低減率は64\%であった。また $10 \mathrm{~cm}$ の位置ではフ イルタを使用で19\%となり線量低減率は $81 \%$ であった (Fig. 5).

\section{4. 考 察}

\section{1 評 価方 法}

1983年 Gray ら ${ }^{9)}$ が全脊椎撮影にフイルタおよび高感 度増感紙などを使用し, 被検者に対しての被曝低減効果 について TLDを用いて測定している．また同年，Fecz$\mathrm{ku} ら^{10)}$ は前者と同様の測定方法で大腸注腸 decubitus 撮影にフイルタを用い，14\%から19\%の被曝線量低減が あると述べている．臨床使用するフイルタの厚さは各部 分により異なるので, 評価する位置を点にとると全体的 な把握ができない.

例えば, 腹部血管造影時のフイルタ位置は Fig. 6 に示 すようになる.フイルタ厚は横隔膜部用では，Aの部分 は20 mm アルミニウム一定だが $\mathrm{A}^{\prime}$ の部分では $0 \mathrm{~mm}$ か ら $20 \mathrm{~mm}$ まで変化している. 同様に, 側腹壁部用でも B 部分は含鉛アクリル $14 \mathrm{~mm}$ 一定だが, B'の部分では 0

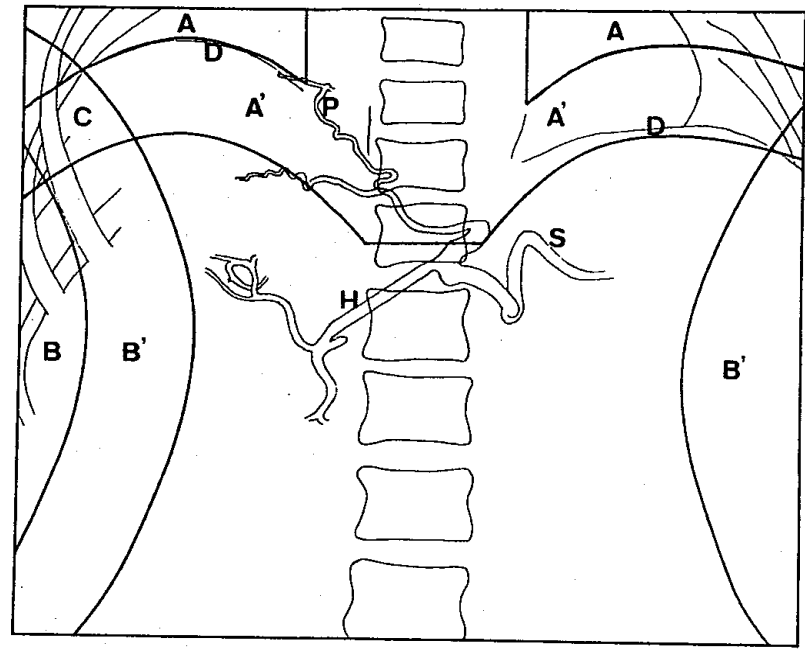

Fig. 6 The filter's areas on one of hepatic angiography.

Marks "A" are maximum thickness areas of a diaphragmatic compensating filter and marks " $\mathrm{A}$ " "are the slope areas of it.

Marks "B" are maximum thickness areas of lateral compensating filters and marks " $\mathrm{B}$ '" are slope areas of these.

Mark " $\mathrm{C}$ " is an overlap area of diaphragmatic compensating filter and lateral filter.

Mark " $D$ " is a diaphragm. Mark " $H$ " is a hepatic artery. Mark " $\mathrm{P}$ " is a subphrenic artery. Mark " $\mathrm{S}$ " is splenic artery.

$\mathrm{mm}$ から $14 \mathrm{~mm}$ まで変化している.このように濃度補償 する部位は, フイルタのスロープ部分が主である.つま り，スロープの部分において TLDなどを用い点による X線量を測定した場合, 評価は不正確となり全体の評価 はできない。

面積線量計を用いて測定した場合は，照射野内のフイ ルタ領域をすべて評価できる。つまり，腹部血管造影の ように被写体外照射野が無い場合，フイルタによって低 減された照射線量は, 被検者に対して低減された照射線 量といえる。

著者らは面積線量計を用いフイル夕挿入領域を含め, 照射野全面において評価した。

\section{2 面積線量と被曝線量}

面積線量の低減率を, 即被曝線量の低減率と考えるこ とはできない.つまり照射野の面積と被写体の面積が同 一でなく, 撮影部位によりその比は異なる。腹部血管造 影では照射野の大きさを被検者の側腹部とするので，照 射野の面積と被写体の面積は同一と考えられる.しかし， 


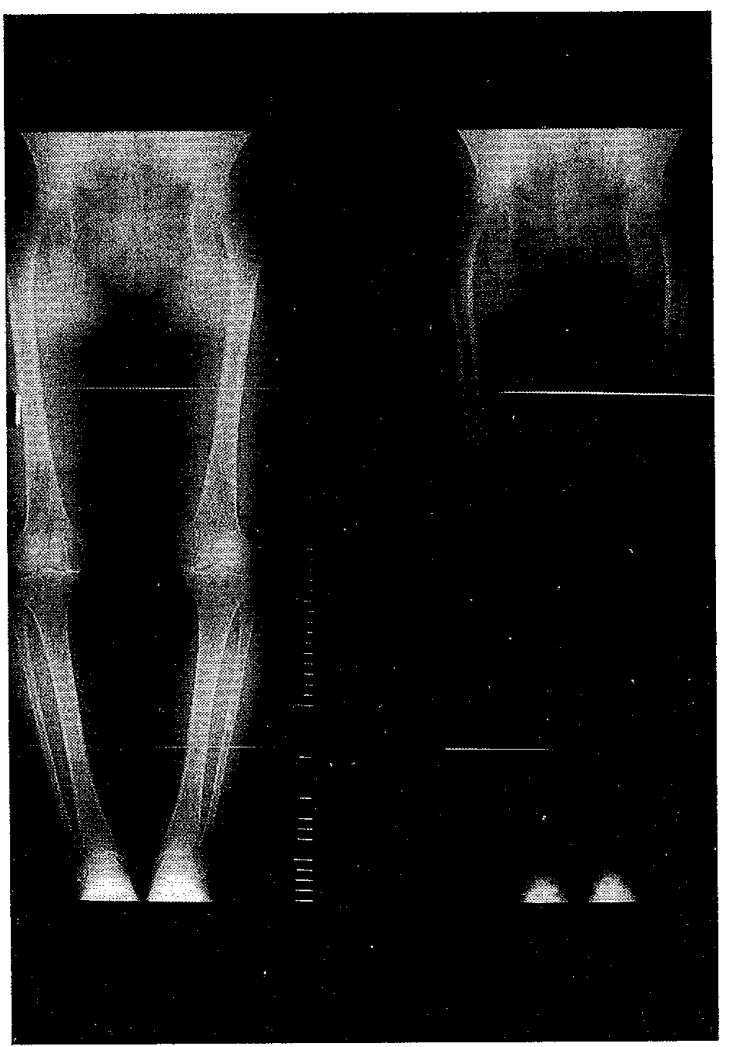

A

B

Fig. 7 Full length lower extremity radiograms with or without a filter are shown. A is a radiograph using a filter combined with gradient screen US-II : from the hip joints to ankle joints were able to be assessed due to similar densities. B is a radiograph using a gradient screen without a filter : melther tibias was not assessed due to an over density.

胸部や他の部位の撮影では照射野は矩形であるのに対し 被写体の形状は様々であり，面積線量計での值には被写 体外照射野の照射線量も含まれる．フイル夕による被曝 線量低隇にはこの被写体外照射野における照射線量の低 減も含まれているので注意する必要がある.

下肢長尺撮影ではフイルタ形状が股関節から足関節の 方向に厚さが変化しているので，照射野の巾にかかわら ず照射線量低減率は一定と考える. Fig. 7A,B に臨床写 真を示す。

頭部単純撮影のように被写体が複雑な形状の場合, 線 量の評価は困難である，当成人病センターにおける頭部 単純撮影は平行絞りに円形絞りを併用している. 被写体 外照射野は少なく，面積線量により評価しても問題はな いと考える。

\subsection{X線管負荷の増加と被曝線量の変化}

Feczku ら ${ }^{10)}$ は大腸注腸 decubitus 撮影にフイルタを 用い，14\%から $19 \%$ の被曝線量低減があるが，X線管負 荷の増加が管電流で30\%から $142 \%$ あると述べている.し かし, 測定点はフイルタ挿入部分であり, フイルタ未挿 入領域での被懪線量については検討されていない. 著者 らの実験でも，頭部撮影においてX線管負荷は $12 \%$ の $\mathrm{mAs}$ 值の増加として認められた。しかし $\mathrm{Mix}-\mathrm{Dp}$ の 5 $\mathrm{cm}$ 深部に扔ける吸収線量は, 頭部フイルタを挿入して も非挿入部分の変化にほとんど影響なく，X線中心軸上 で $4 \%$ の増加であり, $2.5 \mathrm{~cm}$ 離れた位置では増加はなか った. 腹部血管造影において側方フイルタのみを使用し た場合は，X線管負荷の増加は認められず，横隔膜フイ ル夕を同時に使用すると撮影時間で $9.5 \%$ の増加があっ た.この理由として Photo timer の受光部の大きさと位 置，基準とする適正濃度領域の設定位置の異なり，ある いはフイルタ領域の異なりなどによると考えられる。ま た，下肢長尺撮影ではフイルタ使用，非使用とも同一撮 影条件にて撮影したが大腿骨骨頭部の濃度に変化はなか った.

\section{4 フイルタの設定位置}

Vezina ら ${ }^{11)}$ は1985年に肩部濃度補償に対しシリコン 製のフイルタを被写体とフイルムとの間に位置させ，濃 度補償と撮影体位に対し利点を述べている。しかし，フ イルタを被写体とフイルムとの間に位置させると，X線 は被写体を透過した後に補償され，被曝線量の減少に関 与しない．被検者の被曝の問題を考慮するならば適切な 方法であるとは言えない，著者らはX線管と被写体の間 (コリメーター前面)にフイルタを取り付けることにより 面積線量で29\%以上低減した。つまり被検者の被曝の問 題を考虑するならばフイルタはX線管と被写体の間に位 置させるべきである.

\section{5.おわりに}

測定結果から, フイルタの面積線量低減率は, 重要な 值を示しているといえる.フイルタを用いると面積線量 が低減され，ファントム実験の結果から吸収線量も低減 された。また，フイルタ非挿入部分に扔ける吸収線量は X線管負荷が増加した場合でもほとんど増加しなかった。 すなわち，通常の X線撮影時フィル夕を使用頻度を高め ることは被検者の被懪低減に役立つと考える.

謝辞

稿を終えるにあたり本研究をご指導いただきました当 成人病センター放射線診断科部長黑田純知医師, ならび 
にご協力下さいました放射線技師諸兄に感謝いたします。 なお，本研究の一部は第 3 回大阪府放射線技師学術大会 にて発表した。

\section{参考文献}

1) Katsuda T., Hori S., Fujita M., et al.: A diaphragmatic compensating filter for hepatic angiography. Radiography today, 57, 646, 20-23, (1991).

2) Smith DC., John T.: Adjustable sliding alminum wedge filter: device for angiographic enhancement. Radiol. Technol, 49, 4, 459-471, (1977).

3) Crow W., Guinto, Jr FC., Segura T.: Aluminumwedge filter for improve arch aortograms. Radiology, 146, 5, 542, (1983).

4) Peterson R., Rohr, Jr W.: Improved assessment for lower extremity aligment using new roentgenographic techniques. Clin. Orthop. 219, 112119, (1987).

5) Marugg S., Streule K., Hedtler W., et al. : Addi- tive filtering. Bri. J. Radiol, 63, 800-801, (1990).

6）勝田稔三，桑野忠雄，中島，直，他：肝動脈造影に おける濃度補償フイルタ（横隔膜フイルタ）の検討。 日放技学，45，12，1825-1831，(1989).

7）新開英秀：腹部血管造影撮影における技術的緒問題. 日放技学，31，3，221-230，(1975).

8）桑野忠雄, 勝田稔三, 中島 直, 他：下肢長尺撮影 における補償フイルタの一考察．日放技学関西支部 報, 3，16-17，(1990)。

9) Gray JE., Hoffman AD., Peterson MA. : Reduction of radiation exposure during radiography for scoliosis. J. Bone and Joint Surg. 65-A, 1, 5-12, (1983).

10) Feczku PJ., Haggar AM., Rauch PL., et al.: Compensation filtration for decubitus radiography during double-contrast barium enema examination. Radiology, 49, 3, 848-850, (1983).

11) Vezina LA. : Compensation filter for shoulder radiography. Radiology, 155, 3, 823, (1985).

本誌11号所載の論文「コンピューテッドラジオグラフィにおけるレーザープリンタ のウィナースペクトル測定について誤りがありました．訂正いたします。

-p. 1941 左22行目 Fig. $1 \rightarrow$ Fig. 2

Fig. $2 \rightarrow$ Fig. 3

右 3 行目 Fig. $3 \rightarrow$ Fig. 4 (2力所)

- p. 1942 左 1 行目 Fig. $3 \rightarrow$ Fig. 4

右 1 行目 Fig. $1 \rightarrow$ Fig. 2

- p. 1943 左 9 行目 Fig. 1，3 $\rightarrow$ Fig. 2, 4

左19行目 Fig. 4 Fig. 5 (2 力所)

左26行目 Fig. $4 \rightarrow$ Fig. 5

-p.1944 右 9 行目 文献11)に追加

Proc. SPIE 914, 877-891 (1988). 